\title{
A música em cena na Belle Époque paulistana $^{1}$
}

\author{
José Geraldo Vinci de Moraes $^{2}$ \\ Denise Sella Fonseca ${ }^{3}$
}

\section{Resumo}

No período entre os últimos anos do século XIX até as duas primeiras décadas do século $\mathrm{XX}$, tiveram lugar na cena musical paulistana gêneros teatrais cujo objetivo central era divertir o grande público acima de qualquer outra pretensão. Apesar de cada um deles ter suas próprias convenções e dinâmica de funcionamento, todos tinham na música elemento essencial ao espetáculo. A designação "teatro de revista" tornou-se referência e serviu para nomear um conjunto bem maior de modalidades, que inclui operetas, burletas, mágicas, vaudeviles, zarzuelas, fantasias, entre outras. Elemento importante na produção e divulgação da música no espaço urbano antes do aparecimento e consolidação dos meios de comunicação eletrônicos, o estudo do teatro musicado nos seus diversos e complexos aspectos pode ser fundamental para a compreensão do panorama da música e da cultura popular na cidade de São Paulo.

\section{Palavras-chave}

Música popular, teatro musicado, São Paulo.

Recebido em 4 de novembro de 2011

Aprovado em 8 de dezembro de 2011

1 Este artigo é produto de investigações que contaram com apoio à pesquisa do CNPq e da Fapesp.

2 Professor de Teoria e Metodologia da História e dos Programas de Pós-Graduação em História Social e de Música da Universidade de São Paulo (USP). É pesquisador CNPq. E-mail: zgeraldo@usp.br

3 Mestranda no Programa de Pós-Graduação em História Social, FFLCH-USP, onde desenvolve a dissertação O teatro musicado paulistano na Belle Époque, 2011. É bolsista Fapesp. E-mail: denise.fonseca@usp.br 


\title{
Stage Music During the São Paulo Belle Époque
}

\author{
José Geraldo Vinci de Moraes \\ Denise Sella Fonseca
}

\begin{abstract}
In the period covering the last years of the nineteenth century to the first two decades of the twentieth century, São Paulo had the music scene as one of its main theatrical genres aimed at a wider audience, which the central objective was to divert him above any other purpose. Although each one of them have their own conventions and working dinamics, in all of them music was an essencial element in the show. The designation "teatro de revista" has become a reference and has served to name a much greater set of modalities including operetta, burleta, magic, vaudeville, zarzuela, fantasy, among others. As an important element in the production and dissemination of music in urban space befor the emergence and consolidation of the eletronic media, the study of musical theather in its various and complex aspects can be essencial to understand the music scene and popular culture in São Paulo city.
\end{abstract}

\section{Keywords}

Popular music, musical theater, São Paulo. 


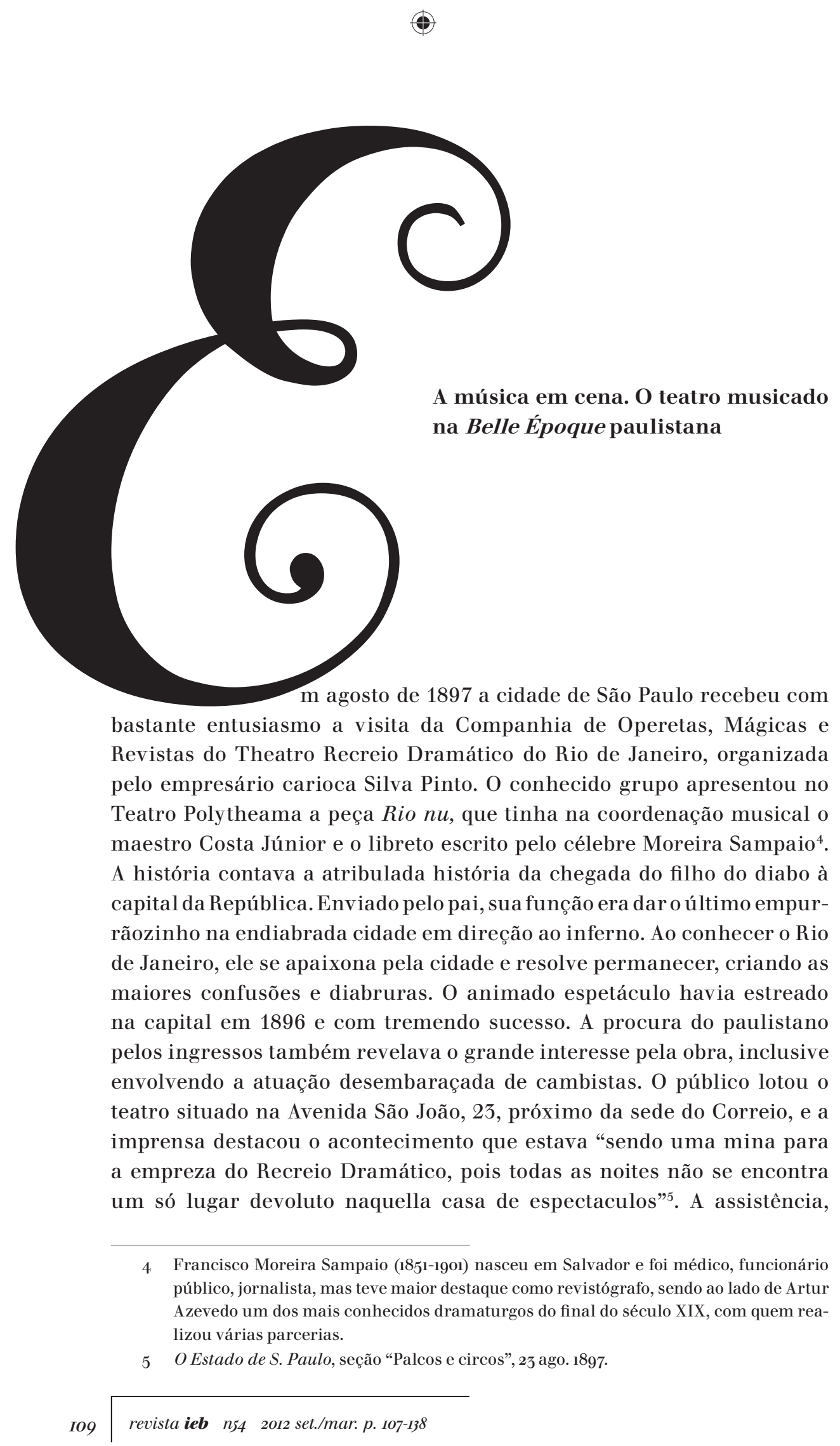


sempre muito inquieta e estridente, se entusiasmou com as apresentações do ator França, obrigado a "bisar uma dúzia de vezes as cantigas", e com os maxixes da cantora Magdalena Vallet, que foi ovacionada pelo "gallinheiro", já que dançou e requebrou numa "verdadeira gymnastica de corpo". Já a famosa atriz-cantora Medina de Souza e o ator Affonso, considerado um novo talento, não tiveram como "galardão as palmas" do público que, segundo o crítico do jornal O Estado de S. Paulo, não soube avaliar seu "dificil e correcto trabalho".

Estes espetáculos musicados ocupavam à época boa parte da programação do Polytheama, assim como de outros teatros da cidade. Mas nem todos eram festejados e alcançavam o sucesso desta revista musical carioca. No ano seguinte, por exemplo, o teatro recebeu entre os meses de outubro e novembro a Companhia Espanhola de Zarzuelas Valentim Garrido, que apresentou canções da "bella música hespanhola". O grupo tinha como especialidade pequenas zarzuelas em um ato, apresentando canções como "El duo de l'Africana" e as espirituosas "Las Amapolas" e "La Banda de Trompetas". Desta vez a plateia não recebeu com o costumeiro entusiasmo o reconhecido grupo, deixando a casa quase vazia na primeira semana de turnê. Na avaliação do crítico, a qualidade da Companhia e o programa atraente mereciam retorno positivo dos espectadores: "com um programa tão interessante é de esperar uma enchente à cunha”. Para ele a atitude indiferente do paulistano, apesar de se queixar muito da "falta absoluta de divertimentos públicos, numa cidade já tão populosa" ${ }^{\prime}$, revelava sua incapacidade de aproveitar um trabalho de "nível".

O fato principal que se revela nestes dois casos distintos é a existência, na passagem do século XIX para o XX, de certo circuito musical na cidade, composto por um repertório do teatro musicado, seus artistas, público e a "crítica especializada". Na verdade, essa rede musical estava associada à dinâmica cultural mais ampla de florescimento e expansão da cultura urbana do entretenimento e das artes em São Paulo. Acompanhando o crescimento acelerado da cidade, neste período o mundo das diversões teve expansão evidente, protagonizado por diversos tipos de espetáculos, boa parte deles formada pelo teatro musicado. Ele oferecia especialmente uma atraente combinação de elementos de cena (humor, drama e crônica), coreográficos e, sobretudo, de músicas diversas, principalmente, canções. Ao congregar e misturar elementos variados, geralmente muito próximos da vida cotidiana, o gênero atraía as novas populações urbanas. Assim como ocorria na capital do país e em outros

$6 \quad$ Idem. 29 out. 1898. 
centros urbanos importantes, esses espetáculos de variedades baseados na cena musicada também marcaram a cidade de São Paulo de forma acentuada e permanente na passagem dos séculos.

Apesar desta viva presença no cenário cultural e musical que agitava o novo cotidiano urbano, a entrada do teatro musicado no universo das investigações acadêmicas é algo ainda muito recente. A despeito dessa condição, a clássica historiografia da música popular sempre reconheceu sua importância na formação e circulação musical para o período que antecede a expansão dos meios de comunicação eletroeletrônicos. Ao mesmo tempo, a matéria também tem sido debatida em um quadro mais amplo e elucidativo sobre o universo cultural da Belle Épóque, mas quase sempre vinculado à cidade do Rio de Janeiro. Sua configuração na capital paulista permanece ainda pouco conhecida ${ }^{7}$, provavelmente produto da indiferença da historiografia, que consequentemente limitou a produção bibliográfica e dificultou a criação de acervos e bases documentais franqueados a esse tipo de objeto. Ocorre que livros, fontes e documentos não aparecem naturalmente como "mágicas" nas bibliotecas, acervos e arquivos: suas presenças dependem exclusivamente "de causas humanas" . $\mathrm{O}$ alerta de Marc Bloch reforça a necessidade de abordar o tema, associada à importância imperativa do trabalho documental. Mas a raridade das fontes que tratam da música popular em cena na cidade e a dificuldade em acessá-las e manuseá-las obrigam o investigador a procurar formas alternativas para conhecer e compreender esse universo da cultura popular paulistana. Sua memória particularmente instável - como de resto de boa parte das culturas populares urbanas -, produto da prática musical evanescente, associada à inexistência de seu registro escrito e fonográfico,

7 Neyde Veneziano é considerada pioneira no estudo acadêmico do tema. Sua obra ajuda a lançar luz e sugerir caminhos para a pesquisa do assunto. Ver VENEZIANO, Neyde. De pernas para o ar-Teatro de revista em São Paulo. São Paulo: Imprensa Oficial, 20o6. No universo acadêmico, outros pesquisadores também estudaram o tema, como ARAÚJO, Vitor Gabriel de. Zarzuela: o teatro musical espanhol em São Paulo. Tese (Doutorado em História) - Faculdade de Ciências e Letras-Unesp, Assis, 2ooo; MELO, Cássio Santos. Caipiras no palco: teatro na São Paulo da Primeira República. Dissertação (Mestrado em História) - Faculdade de Ciências e Letras de Assis-Unesp, 20o7; LEANDRO, Marcelo Tupinambá. A criação musical e o sentido da obra de Marcello Tupynambá na música brasileira (I9I0-1930). Dissertação (Mestrado em Música) - ECA-USP, 2005; OLIVEIRA, Aline Mendes de. O Theatro Polytheama em São Paulo: uma visão múltipla do teatro, do circo e do cinema em São Paulo do século XIX. Dissertação (Mestrado em Artes) - ECA-USP, 2005; MARIANO, Maira. Um resgate do teatro nacional: O teatro brasileiro nas revistas de São Paulo. Dissertação (Mestrado em Literatura Brasileira) - FFLCH-USP, 2008; BESSA, Virginia de Almeida. A cena musical paulistana: teatro musicado e canção popular na cidade de São Paulo (1914-1934). Tese (Doutorado em História Social) - FFLCH-USP, 2012.

8 BLOCH, Marc. Uma introdução à história. São Paulo: Brasiliense, 1981. p. 65-6. 
é apenas obstáculo inicial. A ausência dos libretos que costuravam o texto e davam unidade à obra é outra dificuldade que se apresenta de maneira recorrente. Sem eles, restam apenas fragmentos das histórias, e o universo musical de escutas permanece desconhecido, quase intangível. E o perfil caracteristicamente cronista e circunstancial do gênero proporciona finalmente problema suplementar. A sujeição de divertir as plateias obrigava os autores a empilhar novidades sobre novidades, forçando o texto a seguir a dinâmica dos eventos e vogas da temporada. Isso significava mudanças constantes nos textos literários e musicais, e muitas vezes seu esquecimento imediato e desaparecimento junto com a passagem do acontecimento e da moda. Essa condição efêmera determinava usos e reusos dos textos, dos quadros e das canções, que transitavam por várias obras, mudando ao sabor das circunstâncias.

Certamente essas condições delineiam panorama um tanto severo para as investigações. Parece então que resta por ora seguir o método luminoso de Machado de Assis, que consiste em apertar os olhos e "enxergar onde as grandes vistas não pegam", para "catar o mínimo e o escondido". Provavelmente isso significa trabalhar com os resíduos da memória individual e da coletiva, presentes nos vestígios e escritos memorialísticos diretos e indiretos de artistas, das plateias e os que assumiam forma pública. Neste cenário rarefeito, os registros anotados pela imprensa cultural em gestação e a periódica tendem a se revelar fonte permanente e rica. O acompanhamento em série dos periódicos pode informar o cenário do teatro musicado paulistano e também como se dava a construção do gosto musical. A partir desses dados, vasculhar e compulsar os resíduos fonográficos e aqueles editados em forma de partituras torna-se exigência, ainda que muitas vezes improdutiva. Assim, arriscando-se pelo inspirador "método do míope" de Machado, talvez seja possível aproximar-se de elementos que compunham a cena musical paulistana na passagem dos séculos XIX e XX e compreender melhor a história cultural da cidade.

\section{A febre de teatros em São Paulo}

Ainda que de maneira precária e às vezes muito presumida, já se sabe que um conjunto mais variado de diversões ligadas intrinsecamente

9 ASSIS, Machado de. 11 de novembro de 1987. In:__. Melhores crônicas de Machado de Assis. Seleção e prefácio Salete A. Cara. São Paulo: Global, 2005. p. 394. Coleção Melhores crônicas

revista ieb $\quad$ n54 2012 set./mar. p. I07-138 
ao mundo urbano começou a se estabelecer na capital paulista a partir dos anos 1890. Até essa década, a cidade contava com poucas iniciativas ligadas ao teatro, especialmente o musicado. Desde meados do século XIX, sua vida teatral praticamente resumia-se ao amadorismo dos acadêmicos da Faculdade de Direito e às raras apresentações nos teatros São José (1864) e Provisório (1873), sucessores da antiga Casa da Ópera ${ }^{10}$, por muito tempo o único palco representativo da cidade. Seguindo o ritmo acelerado de crescimento da cidade, entre a década de 1890 e o início do século XX começou a surgir rapidamente um número considerável de estabelecimentos teatrais. Neste período, a cidade foi tomada pela adaptação e principalmente a construção de novos edifícios, como o do teatro Polytheama Nacional (1892), Apolo (1895), Eldorado Paulista ${ }^{11}$ (1899), Santana $^{12}$ (1900), Eldorado ${ }^{13}$ (1900), Carlos Gomes ${ }^{14}$ (1905), São Paulo (em 1907 encontrava-se em construção), Colombo (1908), o novo São José (1909), Cassino ${ }^{15}$ (1909), Teatro Municipal (1911), Palace Theatre ${ }^{16}$ (1913), Cassino Antártica (1913), Esperia (1914), Braz Polytheama (1914), Boa Vista (1916), Royal Theatre (1916), São Pedro (1917) e Avenida (1918). Acompanhando a expansão física da cidade e sua desordenada transformação urbana, essa febre de teatros foi encerrada no final da segunda década do século XX. No decorrer dos anos 1920 o ritmo das construções diminuiu drasticamente, e muitos deles chegaram a ser transformados em cinemas ou mesmo a desaparecer, envolvidos pelo novo fluxo de crescimento da cidade, pela especulação imobiliária, além dos casos corriqueiros de deterioração dos edifícios e de graves acidentes causados sobretudo por incêndios.

Certamente esse investimento revela a incrível dinâmica cultural e musical que a cidade começava a experimentar. Desde o final do século XIX a elite paulistana frequentava e divertia-se no Polytheama, no

10 Em funcionamento desde o final do século XVIII e demolida em 1870, era a principal casa de eventos musicais do período. Ver MORAES, José Geraldo Vinci de. Arranjos e timbres da música em São Paulo, e AZEVEDO, Elizabeth R. O teatro em São Paulo. In: PORTA, Paula (org.). História da cidade de São Paulo: a cidade colonial 1554-1822. São Paulo: Paz e Terra, 2004.

11 A partir de 1901, passa a se chamar Cassino Paulista e, em 1907, o nome é alterado para Bijou. (AZEVEDO, Elizabeth R. op. cit. p. 577.)

12 Antigo Teatro Provisório. (Idem.)

13 Posteriormente, teria seu nome alterado para Éden Teatro. (Idem.)

14. A partir de 1906, passou a se chamar Moulin Rouge; em 1911, foi renomeado Variedades e, posteriormente, Avenida. (Idem. p. 578.)

15 A partir de 1913, passa a se chamar Apollo e, posteriormente, volta a se chamar Cassino. (Idem. p. 579.)

16 A partir de 1916, passa a se chamar Palácio Teatro. (Idem. p. 579.) 
Colombo, mas principalmente no Santana, no Boa Vista e no São José. Na verdade essas três últimas casas foram construídas por poderosas famílias paulistas: o Teatro Santana, considerado o melhor da época, foi erguido com apoio da família Álvares Penteado; o São José era da família Prado; e o Boa Vista pertencia aos Mesquita, proprietários do jornal O Estado de $S$. Paulo $^{17}$. Essas casas apresentavam regularmente companhias de operetas e zarzuelas, espetáculos dramáticos e cômicos, como também recebiam os concertos, temporadas líricas e de óperas. No entanto, sua estrutura sempre foi precária e limitada. Nenhum deles, por exemplo, tinha fosso adequado para abrigar orquestras maiores ou então palco com profundidade suficiente para récitas de óperas com diversos atos. Além dos problemas estruturais, a dificuldade de obter na cidade instrumentistas profissionais e qualificados para participar e contribuir nos concertos e espetáculos era obstáculo adicional. A exceção de sempre eram os pianistas, condição que Mário de Andrade sempre reclamou e criticou, apontando para os excessos da "pianolatria" paulistana, originada no século XIX. Esse quadro musical instável e indigente gerava muita insatisfação e protestos por parte da crítica e da elite de gosto musical europeizado. Para reverter as carências e atender a demanda cultural crescente, no início do século XX foram criadas duas instituições fundamentais para o desenvolvimento e a sobrevivência do circuito musical na cidade: $\mathrm{o}$ Conservatório Dramático e Musical e o Teatro Municipal de São Paulo.

O conservatório, fundado em 1906, pretendia formar músicos e instrumentistas competentes, como revela Mário de Andrade em seu discurso de paraninfo aos formandos da turma de 1922: "o Conservatório vos confere seu diploma de mérito artístico. Isso quer dizer que sois artistas agora (...). Quero ver-vos sair daqui inteiramente conscientes de vossa missão"18. No entanto, por força das tensões culturais presentes na cidade, a instituição desempenhou também durante bom tempo papel de destaque

17 Aliás, a tradicional aristocracia rural cafeeira não só se adapta, como determina os rumos da nova e moderna vida cultural urbana. É curioso, por exemplo, observar como ela foi também muito atuante nos destinos da vida esportiva paulistana, inclusive na implantação dos clubes e equipes de futebol. Veja, sobre o assunto, GAMBETA, Wilson Roberto. Templo do esporte. O Velódromo Paulista nas origens do futebol (1895-1915). Tese (Doutorado em História Social) - FFLCH-USP, 2012.

18 ANDRADE, Mário de. Discurso pronunciado pelo distinto professor Mário de Andrade, na sessão de entrega dos diplomas aos alunos que concluíram seus cursos em 1922, realizada a 10 do corrente, no Salão do Conservatório Dramático e Musical de São Paulo, sendo o orador paraninfo nomeado pelos diplomandos. São Paulo, Correio Paulistano, 9 mar. 1923. Apud Recortes III, p. 38/9, Série Recortes, Arquivo Mário de Andrade, Instituto de Estudos Brasileiros, Universidade de São Paulo.

II4 revista ieb $\quad$ n54 2012 set./mar. p. $107-138$ 
na construção do gosto musical da elite paulistana, assumindo assim "uma função cultural muito mais pedagógica" ${ }^{19}$ do que estritamente técnica.

Definida a questão da formação musical formal, era necessário criar um espaço adequado para difundir a "boa música" e receber seus intérpretes e divulgadores. Desde o final do século XIX, a Câmara e a administração municipal cogitavam criar um teatro com condições mais modernas. Logo no início do século seguinte os problemas administrativos e financeiros foram destravados, e lançada a pedra fundamental. Em 1911 finalmente foi inaugurado o Theatro Municipal da Cidade de São Paulo, com a ópera Hamlet, de Ambroise Thomas, tendo no papel principal o célebre barítono Tito Rufo. A partir desse momento, o Municipal, com a grandiosidade e o luxo correspondentes à riqueza gerada pelo café, e com seu grande palco capaz de receber qualquer companhia lírica estrangeira ou grande orquestra, tornou-se o polo central das atividades relacionadas à "boa música".

Ocorre que a vida musical na cidade era bem mais diversificada. Ela podia ser fruída em diversos outros ambientes e palcos de cafés, confeitarias, bares, cinemas e pequenos auditórios de salões e até em sociedades beneficentes e políticas ${ }^{20}$. Os palcos mais estruturados recebiam espetáculos musicais com características mais populares e programação variada, como sublinhado logo no início. Na moderna vida urbana, o entretenimento de modo geral e sem distinção social tornava-se cada vez mais bem cultural presente e necessário, já apontando para a produção e divulgação em grande escala, como já ocorria em Londres, Paris e Berlim ${ }^{21}$. A música em cena, como um dos seus protagonistas, criou um circuito cultural próprio, composto por músicos de várias origens e características, agentes e teatros próprios, e espetá-

19 ANDRADE, Mário de. Evolução social da música no Brasil. In: brasileira. 2. ed. Brasília/São Paulo: MEC/Martins, 1975. p. 17-18.

20 Como, por exemplo, no salão Celso Garcia, pertencente às classes Laboriosas, e na Sociedade de Beneficência Guglielmo Oberdan, que mantinham pequenos palcos, rasos e sem profundidade. A música nestes espaços tinha caráter secundário e servia de atrativo para a militância e o proselitismo anarquista. Ver LIMA, Mariangela Alves Lima; VARGAS, Maria Thereza. Teatro operário em São Paulo. In: PRADO, Antonio Arnoni (org.). Libertários no Brasil. São Paulo: Brasiliense, 1986. p. 171-72. Ver, também, MORAES, José Geraldo Vinci de. Sonoridades paulistanas. Rio de Janeiro: Funarte, 1999.

21 Ver, por exemplo, CHARLOT Monica; MARX, Roland (orgs.). Londres, I85I-I9oI. A era vitoriana ou o triunfo das desigualdades. Rio de Janeiro: Jorge Zahar Editor, 1993; WEBER, Eugen. França fin du siècle. São Paulo: Companhia das Letras/Círculo do Livro, 1988 (Coleção a Vida Cotidiana); SEIGEL, Jerrod. Paris boêmia. Cultura, política e os limites da vida burguesa (1830-1930). Porto Alegre: L\&PM, 1992; RICHARD, Lionel. $A$ República de Weimar (1919-1933). São Paulo: Companhia das Letras/Círculo do Livro, 1988 (Coleção a Vida Cotidiana). 
culos variados. Essa rede colaborou para formar uma prática e um gosto musical na cidade, transportando para o tablado emoções e aspirações compartilhadas por variada plateia.

\section{Músicos, espetáculos e plateia}

Mesmo com a cidade construindo e expandindo seus circuitos musicais, viver profissionalmente da música era ainda uma aventura essencialmente amadora e incerta. Os esforços dos músicos neste cenário artístico ainda rudimentar e confuso eram evidentes, e exigia-se deles vida múltipla, variando as atividades artísticas e associando-as com outras formas de trabalho e sobrevivência. A vida e os registros instáveis deste passado, aliados ao uso corrente de pseudônimos e codinomes, tornam a identificação desses artistas tarefa pouco simples e imprecisa. Neste contexto rarefeito e opaco, a imprensa do período pode constituir-se uma boa fonte de informação.

Os jornais do período geralmente anunciavam na estreia de cada obra seus autores e compositores, pelo menos daquelas que julgavam mais importantes de sublinhar. Um dos que apareciam em destaque era o jornalista Arlindo Leal (1871-1929), que usava também o pseudônimo de J. Eloy e talvez possa ser considerado um dos mais destacados libretistas e letristas desta primeira fase do teatro musicado paulistano. Filho do maestro Antonio Leal, ele conviveu desde cedo com o mundo artístico, arriscando-se como ator amador quando jovem. Depois começou a atuar como revistógrafo, assinando em 1899 o libreto de $A$ crise, em parceria com José Piza, outro autor respeitável com trajetória muito semelhante a sua, já que foi teatrólogo e um jornalista que escreveu várias obras com temática caipira ${ }^{22}$. No mesmo ano Leal estreou a mágica intitulada Belzebu e finalmente a revista Boato ${ }^{25}$, considerada pela historiografia como a primeira "peça paulista". Ambientada no biênio 1897-1898 e com música do maestro Manuel Passos, ela conta as aventuras de uma família humilde e ingênua que sai do interior do estado para viver na capital, tema recorrente nos libretos. Mais tarde ele escreveu outras histórias importantes com essa temática regional,

22 José Gabriel de Toledo Piza: advogado, contista, colaborou na imprensa periódica de São Paulo e do Rio de Janeiro; teatrólogo, foi parceiro de Artur Azevedo em O mambembe (1904). Ver AGUIAR, Flávio. A aventura realista e o teatro musicado. São Paulo: Ed. Senac, 1997. p. 267.

23 Conta a história da atribulada chegada do casal de caipiras, Quitéria e Anastácio, à cidade de São Paulo. (VENEZIANO, Neyde. op. cit. p. 84. )

revista ieb $\quad n_{54} 2012$ set./mar. p. I07-138 
como as burletas sertanejas Cenas da roça (1918) e Flor do sertão (1919), com a música a cargo, respectivamente, dos maestros Pedro Camim e Sotero de Souza. Leal foi também colaborador nos periódicos Revista Theatral (1904), Vida Paulista (1908) e na revista campineira Íris (1905-1906). E por certo tempo diretor da Empresa Teatral Paulista, que reivindicava para si a honra de ser a primeira companhia do teatro musicado organizada em São Paulo ${ }^{24}$.

Como letrista de canções, Leal fez parcerias com vários músicos. Com Canhoto (Américo Jacomino, 1889-1928) compôs "Flor paulista", "Já se acabou", "Triste carnaval" e "Arrependida". Aliás, Canhoto também foi um músico atuante do cenário teatral paulistano, apresentando-se em peças como Cenas da roça, O 31 paulista (1918) e A caipirinha (1919), ao lado da dupla "Os Garridos". Em 1919 formou o trio Viterbo-Abigail-Canhoto para atuar em números teatrais. Porém, o trio foi desfeito rapidamente com a morte trágica do ator Viterbo de Azevedo ${ }^{25}$. Já com Marcelo Tupinambá, Arlindo Leal fez "Viola cantadera", "Tristeza do caboclo", "Ao som da viola", entre outras.

Marcelo Tupinambá (Fernando Lobo, 1892-1953) certamente foi um dos mais conhecidos e influentes compositores da cena musical paulistana do período. Aluno da escola politécnica, Fernando Lobo teve que esconder sua condição de compositor de "teatro de revista" e fez diversas canções sob o pseudônimo de Marcelo Tupinambá, justamente após o sucesso da peça São Paulo futuro, estreada em 1914. Composta em parceria com o reconhecido libretista Danton Vampré (1892-1949), tratava-se de uma revista satírica que contava história semelhante aos textos de Leal e Piza, isto é, as peripécias de um caipira do interior (o Gaudêncio), que chegava à cidade de São Paulo e se metia em inúmeras confusões. Ela alcançou simpatia do público e da crítica, recebendo elogios dos jornais Correio Paulistano e O Estado de S.Paulo: "Vai agradar francamente. A Revista é toda recheada de lindos trechos musicais bem adaptados às diversas cenas (...) foi bem tratada pelos autores, que lhe puseram verve e chiste sem o sel gros comum em trabalhos desse gênero" ${ }^{26}$.

Encenada centenas de vezes, seu sucesso pode ser medido também pela gravação feita por Baiano pela Casa Edson, ainda em 1914, de duas

24. O Estado de S. Paulo, anúncio de 27 jan. 1911.

25 Ver ANTUNES, Gilson Uehara. Américo Jacomino “Canhoto" e o desenvolvimento da arte solística do violão em São Paulo. Dissertação (Mestrado em Música) - ECA-USP, 2002; ESTEPHAN, Sérgio. Viola, minha viola: A obra violonística de Américo Jacomino, o Canhoto (1889 -1928). Tese (Doutorado em História Social) - PUC-SP, 2007.

26 O Estado de S. Paulo, 24 abr. 1914. 
de suas canções, "Cavaleiros do luar" e "São Paulo futuro"27, que logo ganharam as ruas com os gramofones. Portanto, em São Paulo também despontavam as relações de reforço mútuo entre o teatro musicado e a nascente indústria fonográfica, como já ocorria na capital do país e cuja maior expressão na década de 1920 talvez seja Sinhô. ${ }^{28}$ Tupinambá compôs para outras obras e também dezenas de canções, ganhando reconhecimento de Mário de Andrade que, comparando-o a Ernesto Nazareth, o considerava autêntico autor nacional e um dos melhores melodistas do país ${ }^{29}$. Músico com formação e reconhecido pela crítica e público, Tupinambá continuou a carreira artística na década de 1930 na direção musical de várias emissoras de rádio ${ }^{30}$.

Havia outros compositores importantes que davam vida musical à cena, como Benedito de Assis Lorena (1872-1926), Frederico Cotón ${ }^{31} \mathrm{e}$ Sotero de Souza. O primeiro ficou conhecido no cenário musical paulistano como Tenente Lorena, uma vez que era membro da conhecida Banda da Força Pública de São Paulo, além de dirigir outras pequenas orquestras de cinemas e cafés ${ }^{32}$. Tenente Lorena participou da musicalização de várias peças, como Uma festa na Freguesia do Ó e Sem tirar nem pôr (1917); Não lhe bulas, A filha do comendador e A pensão da mulata (1918); e O candidato do povo, Verdades verdadeiras e Bocados e bocadinhos (1919). Além dos números caipiras, que se tornariam cada vez mais comuns, a partir de meados da segunda década do século XX, nas burletas e revistas de que participava, ele incluía quadros com canções carnavalescas, cançonetas, valsas, quadrinhas, maxixes etc.

Lorena fez parceria com Frederico Cotó em vários espetáculos, como a burleta-revista nomeada Nhô Zé Maria no Rio e a burleta $A$ pensão de Dona Anna, ambas de 1917, e também se revezavam nos espetáculos entre São Paulo e a capital federal. As parceiras de Cotó com outros compositores resultaram em uma burleta e três revistas paulistas, entre elas Mau jeito, composta em parceria com Costa de Carvalho, e Sustenta a nota, de 1918, composta conjuntamente com Lorena, Alves da Silva, Carlos de

27 As duas canções podem ser escutadas no site <www.memoriadamusica.com.br>.

28 Ver LEANDRO, Marcelo Tupinambá. op. cit.; e ALMEIDA, Benedito Pires de. Marcelo Tupinambá - Obra musical de Fernando Lobo. Ed. do Autor, 1993.

29 ANDRADE, Mário de. Marcelo Tupinambá. In: . Música doce música. 3. ed. Belo Horizonte: Ed. Itatiaia, 2006.

zo MORAES, José Geraldo Vinci de. Metrópole em sinfonia. História, cultura e música popular em São Paulo (Anos zo). São Paulo: Estação Liberdade/Fapesp, 2000.

31 Também foram encontradas referências a Francisco Cotó, que pode ser pseudônimo, parente de Frederico Cotó ou mesmo um erro de grafia na documentação.

32 IKEDA, Alberto T. Música na cidade em tempo de transformação. São Paulo: 1900-19zo. Dissertação (Mestrado em Comunicação) - ECA-USP, São Paulo, 1986. 
Carvalho e Carlos de Paiva. Ambas foram representadas no Teatro Boa Vista em 1918 pela Companhia Arruda, inclusive com a atuação de Cotó como diretor de orquestra, pela qual recebeu os elogios da crítica de $O$ Estado, que destacou a execução de "um genuino cateretê, bem orchestrado e de bello effeito pela sua espontaneidade e singeleza", e ressaltou que a orquestra foi "habilmente dirigida pelo maestro Frederico Cotó"33.

Sotero de Souza era "musicista assaz conhecido na Paulicéa" reconhecido compositor de burletas regionais, como eram classificadas algumas obras ligadas à temática caipira. Suas obras incluíam formas musicais que poucos anos depois seriam reconhecidas como "música caipira" ou "regional". Esse fato foi importante para despertar interesse no paulistano, como ocorreu em "Temos de tudo" e "O estouro da boiada" (1918); "Não te avexe", "Alma caipira”, "Vida roceira”, "Flor murcha”, "Flor do sertão" e "Nhazinha” (1919). Ele foi também proprietário da Casa Sotero, conhecida loja de instrumentos musicais e partituras localizada na Rua Direita. Em 1913 o estabelecimento foi vendido para seu colega maestro Pedro Camin (1870-1933), que aproveitou e ali fundou a editora Campassi \& Camin, que se caracterizou pela impressão de partituras destes autores. Entre os produtos oferecidos pela Casa havia sempre grande "sortimento especial de músicas para pequenas orquestras próprias para teatros e cinemas" ${ }^{35}$, cujo objetivo certamente era abastecer esse circuito.

O maestro Francisco Russo também manteve uma casa nos mesmos moldes durante a década de 1910. Inicialmente fundada como Casa Ítala, passou a se chamar Casa Mignon e, finalmente, em 1921, Casa Wagner, à Rua Libero Badaró. Russo foi regente e orquestrador de companhias de revistas e da música original de inúmeras peças, como da opereta Alma caipira (1919), justamente ao lado de Sotero de Souza. Seu estabelecimento servia de ponto de encontro e contato para a contratação de músicos destinados às orquestras formadas ao sabor das circunstâncias e da produção de espetáculos. A Casa Manon, fundada em 1917 pelos músicos Dante Zanni (violinista) e Henrique Facchini (flautista), também cultivava o mesmo procedimento, contratando artistas e organizando pequenas orquestras e $\operatorname{conjuntos}^{36}$. Tudo indica que essa era uma prática recorrente, realizada por esse misto de músico e pequeno empresário. Essa condição precisa

33 O Estado de S. Paulo, seção "Palcos e Circos", 3 e 4 jan. 1918.

34 O Furão, n. 244, 17 jan. 1920.

35 ARAÚJO, Vicente. Salões, circos e cinemas de São Paulo. São Paulo: Perspectiva, 1981. p. 320.

36 MORAES, J. G. V. Sonoridades paulistanas. op. cit. p. 165-66; MARCONDES, Marco Antonio (org.). Dicionário da música brasileira: erudita, folclórica e popular. São Paulo: Art Ed. Ltda., 1977. p. 360-362. 
ainda ser investigada de maneira mais cuidadosa, pois, neste panorama de amadorismo e profissionalização precária do músico, o teatro musicado, as Companhias e esses empresários amadores parecem ter tido papel importante na criação de certa rede de trabalho e sobrevivência do artista, como já ocorria em outros centros urbanos.

Com a eclosão da Primeira Guerra Mundial a situação do investimento e da produção local mudou, uma vez que diminuiu a circulação das companhias estrangeiras pelo país e pela cidade. Esse fato obrigou artistas e empresários locais a se responsabilizarem pela produção integral dos espetáculos. Contudo, ao invés de o número deles diminuir, aumentou a olhos vistos, possibilitando a consolidação do mercado musical e de certa "nacionalização" do gênero ${ }^{37}$. Em São Paulo essa condição contribuiu também para o aparecimento de peças com temáticas regionais, bem de acordo com a atmosfera nacionalizante do período, como se verá logo adiante. Com o fim da guerra, começaram a aparecer os empresários profissionais que tiveram oportunidade de acumular capital cultural e financeiro no período anterior. Agentes como José Loureiro, José Gonçalves, Pascoal Segreto e Francisco Serrador passaram a administrar uma extensa rede composta de orquestras próprias, companhias completas, a organização de temporadas e, a partir de certo momento, o arrendamento ou propriedade dos teatros, fechando assim o circuito cultural ${ }^{38}$. Além deles, alguns artistas com certo reconhecimento e sucesso de público também arriscaram organizar suas próprias companhias, como ocorreu com Sebastião Arruda (1879-1933) e Nino Nello (1895-1967), protagonistas do teatro musicado da "fase regionalista". Toda essa organização colaborou para a construção de um mercado e circuito musical mais profissional, e para a formação de um gosto e modelo artístico típico, levando o espetáculo musical paulistano ao auge na década de 1920.

A instabilidade e a precariedade da passagem dos séculos não eram, porém, realidade exclusiva dos "músicos populares". Tanto é que vários artistas com estudo musical formal e "erudito" também participavam deste circuito como forma de sobrevivência e alguns também

37 Como indica, por exemplo, José Ramos Tinhorão, em Música popular. Teatro e cinema. (Petrópolis: Vozes, 1972. p. 27).

38 São inúmeros os exemplos na Europa. Na Alemanha neste período, vários pequenos empresários, percebendo a possibilidade de ganhar algum dinheiro neste setor, investem na produção de espetáculos de variedades e criam suas próprias companhias. Alguns chegam mesmo a alugar ou arrendar os teatros, construindo assim verdadeiros "impérios" do entretenimento, onde as comédias musicais tinham preferência. (RICHARD, Lionel. op. cit. capítulo VIII.) 
por evidente interesse estético e artístico. Francisco Mignone, Armando Belardi, Souza Lima, Alberto Marino, José Maria de Abreu e João Sepe criavam, faziam arranjos ou simplesmente regiam orquestras do teatro musicado ${ }^{59}$. Mignone, por exemplo, escreveu duas operetas e um musical, e sob o pseudônimo de Chico Bororó compôs maxixes, valsas e canções para peças alheias ${ }^{40}$. Armando Belardi também lidou bem de perto com essas circunstâncias. Filho de imigrantes italianos, ainda jovem ingressou na orquestra do antigo Teatro Sant'Anna, e seguiu carreira participando de várias orquestras, como a Italiana de Operetas Ettore Vitale, a de Leopoldo Fróes, com quem compôs a canção "Mimosa"11. Além da ocasional participação na composição de números musicais para as peças, há referências a uma revista de costumes paulista musicada inteiramente por ele. A peça chamava-se Depois t'explico, em dois atos, seis quadros e duas apoteoses, tinha texto de A. Gomes ${ }^{42}$ e foi encenada pela Companhia Raul Coutinho. A estreia ocorreu em 21 de junho de 1918 no Teatro Avenida e foi duramente criticada pelo articulista de $O$ Estado de S. Paulo, que disse: "nenhum dos dois atos fica a dever ao outro: são ambos ruins, absolutamente ruins. Nada há na desconchavada revista que se salve (...)". Essa condição levou o público à "quase sonolência"*3.

Aliás, essas reações dos espectadores eram elementos importantes nos espetáculos e indicavam uma participação muito comum à época. Certamente a alusão à "sonolência" serve justamente para contrastar com a atitude, em regra, inquieta do auditório, quase sempre estridente e interativo, que recebia artistas e quadros com vaias, assobios, apupos, gritos ou aplausos. Era comum os números musicais serem seguidos com voz, palmas ou com bengalas e guarda-chuvas batendo ritmadamente no chão. Muitas vezes a plateia chegava a interferir diretamente no andamento do espetáculo, festejando os artistas em cena aberta ao oferecer flores e corbeilles, ou então, insatisfeita, lançando todo tipo de objeto ao palco. Enquanto os ocupantes dos setores mais caros condenavam esse tipo de comportamento, era essa a maneira de as pessoas mais simples e humildes acompanharem os números

39 MORAES, José Geraldo Vinci de. Metrópole em sinfonia. op. cit. 2000.

40 SILVA, Flávio (org). Francisco Mignone. Catálogo de obras. Rio de Janeiro: Academia Brasileira de Música, 2007.

4,1 A canção foi lançada nos teatros e editada em partitura, mas sem referência a seu nome, fato reclamado pelo músico. Ver BELARDI, Armando. Vocação e arte-memórias de uma vida para a música. São Paulo: Ed. Manon, 1986. p. 16.

42 Trata-se provavelmente do professor Armando Gomes de Araújo, autor do libreto de várias peças, como a burleta Castelos dourados, de 1920, musicada por Sotero de Souza.

43 O Estado de S. Paulo, 22 jun. 1918. 
musicais. Claro que elas se agrupavam nos setores onde os ingressos eram mais baratos, de modo geral localizados na parte superior dos teatros, mais distante do palco e com visibilidade parcial. Tradicionalmente, até os inícios do século XIX esse público sempre ocupava a parte térrea, mais próxima ao tablado e onde a participação era mais ativa e inquieta, intervindo diretamente nos espetáculos. O processo de aburguesamento dos teatros europeus naquele século é que expulsou essa assistência em direção às torrinhas ${ }^{44}$. Essa localização mais elevada associada à estridência participativa levou ao apelido desse setor: "galinheiro". Deste modo, o embate entre música de bom e de mau gosto se transfigurava também em procedimento correto e incorreto para escutá-la e penetrava na disputa do espaço físico.

Os espetáculos de sucesso atraíam os mais pobres e a elite à procura de entretenimento, formando uma assistência variada e expondo esses conflitos de maneira clara. As chances de conquistar grandes audiências aumentavam consideravelmente quando a companhia tinha orquestra e músicos de qualidade e bons atores. Bem provavelmente essa plateia estridente não se importava muito com as definições de gênero e as diferenças entre os espetáculos, contanto que a diversão estivesse assegurada. Tudo indica que tanto os espectadores como a nascente crítica experimentavam as atrações sem conseguir necessariamente defini-las com clareza, até porque elas repetiam, replicavam, readaptavam os quadros, procedimentos, melodias, músicas, confundindo-se internamente e, consequentemente, embaralhando o público e a crítica. Certamente esses espetáculos experimentavam dinâmica semelhante àquela que Mário de Andrade chamou de "enorme misturada" de gêneros para a música popular.

\section{A "misturada de gêneros"}

Essa era uma época em que os processos culturais urbanos estavam em formação e os gêneros teatrais e musicais populares em decantação. $\mathrm{Na}$ verdade, essa "tamanha misturada" estava presente nos processos culturais e sociais mais abrangentes. O país, recém-saído da escravidão e da monarquia, lutava para modernizar-se a qualquer custo para vencer os arcaísmos do mundo rural que, no entanto, se apresentava como referência mais autêntica de uma suposta "alma nacional". Nesse período repleto de

44. Ver GORE, Keith. Shftesbury Avenue, as luzes da ribalta. In: CHARLOT, M.; MARX, R. Londres, I85I-I9oI. A era vitoriana ou o triunfo das desigualdades. op. cit. p 108-109. 
indefinições, em que a busca para encontrar a "identidade nacional" era uma espécie de imperativo, a cultura rural deveria ser então resguardada na forma de folclore. Com a expansão e concorrência implacável da cultura urbana, ele deveria ser protegido e divulgado, tornando-se preocupação e eixo de discussão de intelectuais tradicionais e modernistas, mas também se torna "moda sertaneja" nos centros urbanos importantes, revelando-se de diversos modos no teatro e na música. Neste quadro difuso, elementos do mundo tradicional rural se misturavam com fragmentos do universo moderno, apontando para diversas intermediações e fusões. Embora centrais na formação do país que se modernizava, essas culturas construídas fora dos padrões oficiais eram negadas e rejeitadas. Esse era justamente o caso do "teatro de variedades" ou "teatro ligeiro", denominações genéricas que reuniam diferentes gêneros musicados, como as revistas, operetas, burletas, zarzuelas, sainetes, vaudevilles e mágicas. Eles se confundiam e eram vividos como experiências cotidianas sem necessariamente impor rigidamente uma forma ou gênero, necessidade estética e prática comum nas artes formais.

No conjunto classificatório dos "espetáculos de variedades", as revistas e as operetas certamente ocupavam lugar de destaque ${ }^{45}$. De origem francesa, mas introduzida no Brasil pela tradição portuguesa, as revistas eram, ao lado das operetas, os espetáculos musicais mais admirados pela população urbana nos finais do século XIX e por isso mesmo os gêneros mais apresentados. No entanto, em São Paulo, tudo indica que as operetas foram mais encenadas do que as revistas ${ }^{46}$. De qualquer modo, esses dois gêneros foram os que possibilitaram criar um mercado de cultura da música popular. Tanto é que, como já foi salientado, a historiografia da música considera esses espetáculos como centrais na produção e divulgação da música popular no período que antecede a expansão dos meios de comunicação eletrônicos.

Na revista, por definição, o tema central era a revisão de acontecimentos do período e o exame de episódios recentes, sempre sob o viés humorístico e fantástico. Por isso, ao menos no início da voga no país, eram conhecidas também como "revistas de ano". Nelas as referências

45 GUINSBURG, Jacó; FARIA, João Roberto; LIMA, Mariangela (orgs.). Dicionário do teatro brasileiro: temas, formas e conceitos. São Paulo: Sesc-SP/Senac, 20o6. p. 270-71; e VENEZIANO, Neyde. O teatro de revista no Brasil: dramaturgia e convenções. Campinas/São Paulo: Pontes, Ed. da Unicamp, 1991.

46 Neyde Veneziano aponta as revistas como o tipo de espetáculo mais encenado na cidade neste período (VENEZIANO, Neyde. op. cit., 2006). No entanto, os periódicos consultados para o período indicam quadro diferente: entre as 960 peças encenadas e identificadas, 340 eram operetas, 212 revistas e 80 burletas, seguidas pelos outros gêneros. 
cômicas a aspectos da vida cotidiana eram imperativas e indispensáveis. Deste modo, ao mesmo tempo em que exigia vinculação factual com a realidade, o gênero permitia aos autores extrapolar os limites criativos com a invenção de quadros de fantasia e de situações improváveis. A dosagem desses elementos e a forma como eram trabalhados musical e visualmente (cenários, marcações, coreografias, figurinos) eram fundamentais para o sucesso. Não havia roteiro estabelecido: quem criava os possíveis elos eram os compères (compadres). As revistas apresentavam quadros que retratavam de forma original desde casos de amor, eventos do noticiário até personalidades políticas, combinando realidade e doses privilegiadas de humor e fantasia. Os quadros surgiam na forma de paródias, caricaturas, coreografia e muita música. Boa parte deles seguia certa lógica de entrada e encerramento, mas sem rigor algum. Havia na verdade uma infinidade de formas de apresentação e, por isso, comumente elas eram identificadas também por suas características temáticas (política, fantástica, satírica, etc.), de forma (burlesca, satírica, etc.) e origem nacional ou regional (francesa, paulista, etc.). Entre o final do século XIX e início do XX o espetáculo sofreu grande mudança. E após a eclosão da Primeira Guerra Mundial, as revistas começaram a exibir certo caráter regional, com espetáculos que tinham como tema o estado, a cidade e as tradições paulistas ${ }^{47}$.

A opereta também era herdeira direta dos espetáculos líricos de origem francesa, mas alcançou presença e influência em São Paulo seguindo a tradição italiana. Diferente da "revista de ano", ela seguia um roteiro: geralmente um folhetim sentimental com histórias de amor, traições, etc., quase sempre ambientadas na Europa. A trilha musical seguia o mesmo andamento, apresentando gêneros europeus como valsas, quadrilhas, árias de óperas. Por isso, os críticos geralmente martelavam o libreto, mas destacavam o papel educativo na formação do gosto musical da população urbana, sobretudo quando comparava a opereta com a revista, já que esta em geral oferecia música de "gosto duvidoso". Embora algumas peças fossem traduzidas e encenadas por companhias nacionais, na passagem dos séculos a imensa maioria delas era montada por companhias estrangeiras, principalmente as italianas. Neste percurso complicado, o gênero enfrentou problemas para "aclimatar-se" e teve certa dificuldade de "nacionalizar-se", como ocorreu com a burleta.

47 O período posterior é foco da pesquisa de BESSA, Virginia. A cena musical paulistana: canção popular e teatro musicado em São Paulo (1914-1934). Tese (Doutorado em História Social) - FFCLH-USP, 2012.

revista ieb $\quad$ n54 2012 set./mar. p. I07-138 
A burleta estava no meio do caminho entre a revista e a opereta, considerada por isso uma espécie híbrida de "revista de enredo"48. Originada nas óperas cômicas italianas, ao invés de oferecer o painel fantástico e fragmentado de casos como o das revistas, geralmente apresentava um enredo, como nas operetas. Mas diferente delas, o roteiro era formado por vários episódios repletos de humor, muita confusão, conflitos e desencontros. O caráter cômico e a inclusão de música brasileira tornaram o gênero bem popular na cidade, caindo no gosto do público e concorrendo diretamente com as revistas e operetas. A partir do período da Guerra elas tiveram a preferência das companhias locais, assumindo assim papel importante na regionalização temática. Por isso, gradativamente ficaram associadas especialmente aos temas do caipira e do choque entre metrópole e interior, consagrados por autores como Danton Vampré ${ }^{49}$.

Gêneros espanhóis do teatro musicado como as zarzuelas e os sainetes também eram apresentados com recorrência na cidade, como indicado logo no início deste texto. A zarzuela era um espetáculo cantado e encenado por companhias estrangeiras em dois formatos: a grande era uma espécie de ópera muitas vezes cômica; e a pequena (chica), uma opereta que entremeava diálogos, histórias e árias ${ }^{50}$. No final de 1889 o compositor paulistano Alexandre Levy (1864-1892) escreveu, com o pseudônimo de Figarote, no jornal Correio Paulistano diversas críticas sobre as companhias de zarzuelas que se apresentavam na cidade. Intituladas "Companhia hespanhola de Zarzuelas", elas eram quase sempre positivas e destacavam a qualidade das cantoras, "a música saltitante", as "danças nacionais", os trechos cômicos como a "engraçada fantochada cômica-lyrica macarrônica intitulada Comiei”. Mas ele ressalta também a precariedade dos músicos, a desigualdade musical das orquestras e coros das companhias ${ }^{51}$. Tudo indica que prevaleceu na cidade a forma menor, mas sem grande sucesso entre os paulistanos se comparada aos outros gêneros, e já na década de 1910 as zarzuelas raramente eram apresentadas. O sainete também era gênero cômico, mas curto e com menos movimento ${ }^{52}$; a música não era aspecto central na estrutura

48 RUIZ, Roberto. Teatro de revista no Brasil: do início à Primeira Guerra Mundial. Rio de Janeiro: Inacen, 1988.

49 Virginia Bessa aprofunda a discussão deste processo de "nacionalização" pela via "regionalista” em seu doutoramento. op. cit.

50 ARAÚJO, Vitor Gabriel de. op. cit.

51 Correio Paulistano, seção "Palcos e salões", 10 dez. 1889 a ż dez. 1889.

52 MagALDI, Sábato. Cem anos de Teatro em São Paulo. São Paulo: Ed. Senac, 20o1. p. 114. 
e eram geralmente encenados por companhias argentinas. Além deles, eram apresentados também espetáculos de vaudeviles e mágicas ${ }^{5 \pi}$, mas sem a mesma expressão e destaque.

Apesar do esforço na identificação de certas características de tipo, é preciso reconhecer que no início do século XX predominava uma espécie de laboratório das diversas modalidades de entretenimento em um contexto cultural também novo da metrópole paulistana. O público, as companhias nacionais e os críticos ainda estavam construindo as convenções, concepções e o vocabulário adequado aos gêneros representados. E neste contexto prevalecia a mistura e a confusão que se revelava em formas híbridas e curiosas, como burleta-revista, vaudevile-opereta, opereta-revista, cômico-lírico-burlesca. Certamente, o principal aspecto desses gêneros era mesmo a importância da música na estruturação e condução do espetáculo. Dependendo da obra, a música podia cumprir dois papéis principais: o de "texto condutor" e o de "trilha sonora". No primeiro deles, as canções podiam desempenhar a função de roteiro e texto da peça, como era frequente nas revistas, em que muitas vezes a história era contada exclusivamente por meio dos esquetes musicais. No segundo caso, a música seguia a lógica da "trilha sonora", simplesmente acompanhando o espetáculo, como nos casos dos sainetes. É provável também que em muitas situações a música oscilasse entre o texto e a trilha. De qualquer modo, ela sempre ajudava a construir significados e servia para criar os efeitos pretendidos pelos diretores (drama, humor, paixão, etc.).

Independente destas funções básicas, havia certa tensão insolúvel entre a ideia de "música original" e a prática da "música coordenada". Nesse segundo sentido, competia a um ou mais maestros selecionar, "costurar" e arrematar os quadros musicais, construindo verdadeiras "colchas de retalhos" de acordo com a crítica da época. Além disso, como já salientado, os autores eram pressionados pela demanda crescente e permanente por peças novas, fato que tornava essas trocas e misturas um imperativo oportuno. Por fim, há que se considerar que usar músicas já conhecidas do público e "testadas" era mais um fator que poderia

53 Vaudevile é um gênero de origem parisiense supermovimentado, com enredo sempre marcado por quiproquós e situações absurdas cheias de reviravoltas, por meio das quais se alcançava extrema hilaridade. A mágica era um gênero fantástico, chamado na França de féerie, repleto de personagens como fadas, feiticeiros, príncipes e animais falantes, com cenários modernos e deslumbrantes. Havia também, entre as inúmeras modalidades de espetáculos de variedades que estavam em voga naquela época, as apresentações de mímica, igualmente bastante prestigiadas. GUINSBURG, Jacó; FARIA, João Roberto; LIMA, Mariangela (orgs.). op. cit. 
garantir o sucesso do espetáculo. Claro que, num momento em que o circuito musical era incerto e o sistema de reconhecimento de autoria inexistente, esses empréstimos eram corriqueiros e normais, e o critério de originalidade tornava-se questionável ${ }^{54}$. Mas nas colunas teatrais reclamava-se dessas situações indefinidas e recortadas, como se percebe em 1899 no tom azedo do jornal $O$ Estado de S. Paulo:

Quanto à música, também nos pareceu fraca em muitas scenas, pretensiosa em outras, e em todas duma falta de originalidade notavel. A ouverture é feita de reminiscencias sensiveis dos "Palhaços", de Leoncavallo; a música da "carta" tem o cunho caracteristicamente hespanhol; a das "coplas da central", dos "carnavalescos" etc., de uma banalidade extrema (...). ${ }^{55}$

A problemática da originalidade tocava na tensão natural existente entre o trabalho de autoria e a "criação performática" dos artistas de palco, mais do que comuns neste tipo de espetáculo. Aqueles que defendiam a produção autoral pregavam em favor do profundo respeito ao trabalho do autor e do compositor. Não admitiam de modo algum a "collaboração" dos atores tanto no libreto como na música, ainda que isso pudesse ser fator positivo e de sucesso efêmero para determinada obra ou companhia. $\mathrm{O}$ julgamento do trabalho autoral enfatizava principalmente o rigor e a adequação do libreto e da música ao gênero escolhido para cada peça. $\mathrm{E}$ a função dos atores e cantores era estudar com afinco os personagens, de modo a representar de maneira fiel o que pretendia o autor. Matéria de 1898 esboça nesse tom como o bom ator-cantor deveria proceder:

Não podemos admitir que 0 actor collabore quer no libreto, quer na música. O artista consciencioso e digno deste nome colloca a sua arte acima das manifestações transitorias do gosto mais ou menos embotado duma parte do público. Transigir, pois, nestas condições, armar a um effeito que só pode ser ephemero, é desvirtuar por completo a missão do actor. ${ }^{56}$

54 Aliás, essa ação pouco difere das práticas folcloristas de "empréstimos" e circulação das obras musicais e poéticas. Na verdade, a questão da autoria na música urbana começa a ser debatida no final da década de 1910 e a historiografia da música popular selecionou como marco e referência as práticas de apropriação de Sinhô - aliás, um grande compositor para o teatro musicado carioca, onde se consagrou como o "Rei do samba" - e a gravação por Donga de "Pelo telefone", de 1917.

55 O Estado de S. Paulo, seção "Palcos e Circos", 13 mai. 1899. (Grifo nosso.)

56 Idem. 27 nov. 1898 . (Grifo nosso.) 
A análise do desempenho dos músicos e orquestras seguia o mesmo rigor. Reprovava-se qualquer alteração no andamento, ritmo e melodias que descaracterizassem a peça. A Companhia Italiana Tomba ${ }^{57}$, por exemplo, em turnê pela cidade entre fim de 1898 e início de 1899, e novamente em 1902, foi duramente criticada justamente em razão dos cacos inseridos pelos atores em forma de piadas como também pelas improvisações realizadas pela orquestra ${ }^{58}$. Essas modificações podiam se dar tanto com o objetivo de atrair mais público como também pelas tentativas de aproximar-se das operetas francesas, já que os artistas italianos não conseguiam expressar "graça e leveza", alterando a música "devido à vocalização excessivamente emphatica da escola de canto italiano" "59. Essa crítica à performance musical foi muito evidente dois anos depois, na apresentação da opereta cômica Boccaccio, de Franz von Suppé, encenada pela Companhia Italiana de Opereta Zucchi-Ottonello:

Houve, como no espetáculo de estréa, alterações nos andamentos e a ponto de se tornarem desconhecidos alguns trechos da boa partitura (...). O regente tem prenunciada tendência para retardar os andamentos, tirando desse modo a vivacidade e a graça à música de Suppée. As duas últimas scenas do $2^{\circ}$ acto foram detestavelmente marcadas. Felizmente o concertante final deste acto foi bem cantado e attenuou, em parte, o defeito da marcação (....). ${ }^{60}$

Circunstância que também colaborava para aprofundar a confusão eram as adaptações destinadas a alcançar o gosto das plateias paulistanas. Certos espetáculos representados por companhias provenientes do exterior com música basicamente estrangeira geralmente eram modificados por músicos contratados ou pelos próprios regentes da orquestra. Não era raro, por exemplo, companhias portuguesas em busca de sucesso fácil incluírem "exóticos" maxixes buliçosos em suas peças. A revista $O 31$, por exemplo, trazida pela segunda vez ao Teatro São José, em $1918^{61}$, pela Companhia Portuguesa de Operetas e Revistas

57 Em 1898/99 apresentou-se no Teatro Polytheama e em 1902 no Santana. Era dirigida por Raphael Tomba, com Francisco Coniglio como diretor de orquestra. Os principais artistas eram os Srs. Lambiase, Marangoni, Maieroni, Razzoli e as Sras. Marchesi e Flory, entre muitos outros. O corpo de coros da companhia também era numeroso.

58 O Estado de S. Paulo, seção "Palcos e Circos", 4 dez. 1898.

59 Idem. $\mathrm{I}^{\mathrm{o}}$ abr. 1902

60 Idem. 25 nov. 1900.

61 A revista de costumes portugueses protagonizada pelos compadres "17" e " 31 ” já havia sido representada na cidade cerca de dois anos antes. 
dirigida por Henrique Alves, apresentava algumas modificações, como a alteração do final do segundo ato, em que foi inserido "um requebrado maxixe entre bahianas e bohemios da Cidade Nova". A orquestra ficou indecisa e a crítica não entendeu como poderia um maxixe tipicamente nacional figurar numa revista de costumes portugueses ${ }^{62}$.

As companhias cariocas também faziam seus ajustes para aproximar-se do público paulistano, modificando o libreto original ou incluindo quadros adicionais com temática mais regional ou local. Nem sempre essas tentativas eram bem-sucedidas. A incompreensão com essa misturada toda produzia como regra muita insatisfação na nascente crítica musical. Foi o que ocorreu evidentemente em 1888 na revista $O$ homem, de Moreira Sampaio, na qual foi acrescentado o quadro "O homem em São Paulo" e que o Correio Paulistano tratou com comentários amargos:

Enorme enchente afluiu ante ontem ao São José, desejosa de ver o novo acto do Homem passado em São Paulo. O objeto de tanta curiosidade podia ser coisa melhor. A vida em São Paulo já fornece muita coisinha boa da qual um revisteiro podia tirar partido. $\mathrm{O}$ novo acto parece porém antes um pano de reclame, do que um ato de revista. Dentre os tipos apresentados o único que merece menção, pela fiel execução do personagem, foi o que apresentou o provecto artista Colás, imitando um dos sócios da casa de modas Au Bon Marché. Terminou a peça com uma apoteose ao movimento emancipador da província cuja cena apresentava uns simulacros de retratos dos Conselheiros Prado e Antonio Bento. ${ }^{63}$

Curioso que anos depois, em 1917, em outra obra do próprio Moreira Sampaio, a burleta Candinha, esse mesmo tipo de acomodação foi encarada de forma positiva. O texto já era uma adaptação paródica da história da Dama das Camélias, de Alexandre Dumas Filho, e a parte musical de "estilo caipira" parodiava a ópera La Traviata, de Verdi. O ridículo da situação gerava efeito fatalmente cômico, em todos os aspectos, a começar pela protagonista: no lugar de Marguerite Gautier quem brilhava era a Candinha. $\mathrm{E}$ as cenas musicais associavam trechos da conhecida ópera com música regional, ganhando a simpatia popular. As excelentes críticas da imprensa se dirigiram ao texto paródico, à música regional $\mathrm{e}$ à performance da Companhia Arruda. Como se percebe, embora quisesse

62 O Estado de S. Paulo, seção "Palcos e Circos", 16 fev. 1918.

63 Correio Paulistano, seção "Teatro São José”, 7 abr. 1888. p. 2. 
estabelecer critérios modelares estéticos e de forma, a crítica não tinha coerência absoluta neste quadro fragmentário e nem sempre conseguia posicionar-se contrária às adaptações, o que muitas vezes tinha efeito positivo. Isso ocorreu novamente na avaliação da peça Bocados e bocadinhos (1919), uma sobreposição de quadros de várias revistas (por isso a autoria é identificada jocosamente por Toda Gente). A parte musical era uma coletânea, coordenada pelos maestros Tenente Lorena e José Bondoni. Desta feita, o fato de ela não ser original não gerou insatisfação; ao contrário, foi encarado como qualidade: "não é original, como se disse, e nisso vae o seu maior mérito". E a maneira pela qual foram construídas a narrativa e a compilação tornou-se virtude nas mãos de artistas experientes e criativos: "a escolha das scenas para a 'colcha de retalhos' foi feita por quem conhece o métier. Está entremeada de espirito, sem que fosse necessario recorrer a licensiosidade..." ${ }^{64}$.

Para complicar ainda mais o cenário confuso e indeterminado, a esta "misturada de gêneros" teatrais e adaptações as mais variadas associava-se a confusão das formas musicais existente à época. As indefinições dos gêneros da música popular em formação no período são bem conhecidas e talvez seu paroxismo tenha sido indicado por Mário de Andrade na impagável identificação de um certo "sambatangaico" ${ }^{65}$. Os diversos gêneros urbanos como o choro, a marcha e o samba, em decantação, eram introduzidos como experiência e novidades nesses espetáculos. Neles apareciam, acompanhando as peças e esses novos gêneros, as formas híbridas vindas do século XIX, como valsas, polcas, lundus e maxixes, que se misturavam a estilos regionais como cateretês, trovas, canções sertanejas, que, finalmente, conviviam com os últimos gêneros estrangeiros, como tangos, fados, cançonetas can-cans, ragtimes e cake-walks. Como se percebe, nos palcos paulistanos eram divulgadas tanto as modas nacionais como as estrangeiras. $O$ público assimilava as novidades e os comediógrafos passavam a adaptá-las às peças. Desse modo, nada a estranhar com relação à ironia de Mário de Andrade.

\section{A "colcha de retalhos" paulista e a crítica}

Além da instabilidade do teatro musicado, das indefinições dos gêneros da música popular e das ambiguidades e incongruências

64. O Estado de S. Paulo, seção "Palcos e Circos", 14 jun. 1919.

65 ANDRADE, Mário de. Marcelo Tupinambá. op. cit. p. 108.

revista ieb $n_{54} 2012$ set./mar. p. 107-138 
naturais da nascente crítica musical, a partir de meados da década de 1910 ocorreram sensíveis mudanças no panorama cultural paulistano. A nova dinâmica, na verdade, era produto de alguns fatores culturais gerais relativos às indefinições e transições por que passavam o país (como destacado anteriormente, a questão da identidade nacional, nacionalismo, etc.), a cidade (crescimento urbano e demográfico, a "moda" regionalista e "sertaneja"), a primeira fase de consolidação dos gêneros musicais e do "teatro de revista", como também aos eventos específicos relacionados ao aparecimento e crescimento dos espetáculos com temáticas nitidamente regionais. Essa era uma época em que a intelectualidade de modo geral procurava encontrar ansiosamente um "tipo brasileiro" que ultrapassasse as distinções regionais. E, no caso de São Paulo, isso se manifestou antiteticamente na construção de um "tipo paulista" acaipirado ${ }^{66}$.

Claro que todo esse discurso em torno do encontro da consciência e da essência da "alma brasileira" marcou fortemente a definição da originalidade e singularidade do que era a música nacional ${ }^{67}$. Em 1924, ao comentar justamente a obra "típica" de Marcelo Tupinambá, Mário de Andrade afirma que o despertar desta consciência de brasilidade se fez sobretudo por meio da música, posição que ele reafirmaria de maneira manifesta em $1928^{68}$. No final desta década os projetos modernistas procuraram fixar os limites desta brasilidade baseados na ideia do "popular" a partir do folclore (rural e o "urbano"), e estabeleceram como princípio distanciá-la da mera música de entretenimento ${ }^{69}$. Certamente

66 SALIBA, Elias T. Raizes do riso. São Paulo: Companhia das Letras, 2002. p. 124-32 e capítulo 3; SEVCENKO, Nicolau. Orfeu extático na metrópole. São Paulo, sociedade e cultura nos frementes anos 2o. São Paulo: Companhia das Letras, 1992, cap. 4; e LUCA, Tania Regina. A Revista do Brasil. São Paulo: Ed. Unesp, 1999. p. 26o-291.

67 MORAES, J. G. V.; MACHADO, C. Música em conserva. Revista Auditório, Instituto Auditório Ibirapuera, São Paulo, p. 163-18z, 2011.

68 ANDRADE, Mário de. Marcelo Tupinambá. op. cit. p. 104; e Ensaio de música brasileira. São Paulo: Livraria Martins Editora, 1962.

69 Embora se tenham tentado estabelecer esses limites, de qualquer modo esse é um quadro sempre muito instável. No caso de Tupinambá, essa condição se revela de diversos modos. Por exemplo, a sua composição "Maricota sai da chuva" parece ter sido baseada na melodia de um reisado nordestino "Borboleta" (consagrado mais recentemente em gravação de Marisa Monte em 1991), o que estaria de acordo com os ditames da "boa música popular" determinados por Mário de Andrade: o folclore influenciando positivamente a música urbana. Mas por que a situação não poderia ser inversa, ou seja, a composição de Tupinambá teria influenciado grupos folclóricos nordestinos? Essa situação, por exemplo, ocorreu nas gravações da Missão folclórica de 1938, em que foram registrados grupos de Boi de Belém cantando "Pelo telefone" e "Se você jurar", respectivamente de Donga e Ismael Silva, como melodias folclóricas, e sem que os membros da Missão reconhecessem tal fato (ver sobre 
toda essa atmosfera cultural ecoou no teatro musicado paulistano, que participou dela a seu modo, multiplicando peças com temática regional, construindo tipos e mitos.

O quadro nacionalista com conteúdos regionais era efervescente em São Paulo. Depois da fase "protorregional" em que os temas paulistas apareciam apenas como auxiliares, começaram a surgir e a se multiplicar as revistas e as burletas "típicas" com temáticas regionais $^{70}$. E foi nesta mesma época que Cornélio Pires apresentou suas peculiares "conferências" com fortes tonalidades regionais. Em 1910, ele encenou pela primeira vez uma delas no Colégio Mackenzie, mesclando um velório caipira, histórias, piadas e dupla de violeiros. Na verdade, essas "conferências" eram autênticos espetáculos musicados e, provavelmente em razão da forma e conteúdo, tiveram rápida e inesperada repercussão do público. $\mathrm{O}$ espectador que os frequentava na capital era diversificado e semelhante ao do "teatro ligeiro": variava de camadas mais "populares" à gente da classe média e da burguesia ilustrada interessada nos temas regionalizantes. Em um deles, encenado em 1914 no Cine Campos Elíseos, estiveram presentes várias personalidades, como o conselheiro Antonio Prado e o prefeito Washington Luís ${ }^{71}$. Este modelo composto de música, histórias e anedotas, sempre contadas em dialeto caipira, acabaria consagrando-se no cenário dos espetáculos, depois seria transportado para o disco e, com sucesso, para as emissoras de rádio na década de $1930^{72}$.

Seguindo nesse mesmo tom, no ano seguinte Afonso Arinos, fervoroso defensor das causas nacionais e tradições sertanejas, fez também uma série de "espetáculos-palestras", promovida pela Socie-

o assunto MORAES, J. G. V. "E Se você jurar, Pelo telefone, que estou na Missão de Pesquisas Folclóricas?”. Revista USP, Dossiê Música, São Paulo, n. 87, p. 172-183, setembro/novembro/2010). Além do mais, a mesma melodia é encontrada também na composição "Roceiro", de Eduardo Bourdot Filho, compositor contemporâneo de Tupinambá e autor de revistas paulistas como Na ponta da faca (1914) e Não te avexe (1919). Seria a mesma base folclórica a influenciar os compositores, uma imitação ou a prática dos "usos e reusos" de canções no teatro de revista? E, por fim, como se sabe bem, Darius Milhaud utilizou a mesma melodia - entre inúmeras outras fontes da música brasileira - para compor passagem de Le boeuf sur le toit (1919). As referências musicais podem ser escutadas em <www.memoriadamusica. com.br > e também em <http://daniellathompson.com/Texts/Le_Boeuf/>.

70 Ver BESSA, Virginia. op. cit.

71 DANTAS Macedo, Cornélio Pires. Criação e riso. São Paulo: Livraria Duas Cidades/ Secretaria da Cultura, Ciência e Tecnologia de São Paulo, 1978.

72 MORAES, José Geraldo Vinci de. Metrópole em sinfonia. op. cit. p. 234-248. Ver processo semelhante na Alemanha, In: RICHARD, Lionel. op. cit. p. 218. 
dade de Cultura Artística. Em 31 de janeiro o jornal O Estado de $S$. Paulo anunciava:

o brilhante homem de letras, sr. dr. Afonso Arinos, por cuja conferência há grande curiosidade nesta capital. $\mathrm{O}$ distinto acadêmico escolheu para assunto da sua conferência 'As lendas e tradições do Brasil', assunto tão copioso e sugestivo que com certeza dará matéria para mais de uma palestra. ${ }^{73}$

No começo de fevereiro teve início a série que se prolongou até o mês de abril. O Estado e o Correio Paulistano destacaram o sucesso das primeiras apresentações ocorridas no salão do Clube Germânia, que ficou “completamente cheio (...). Os ouvintes ficaram delicadamente presos à palavra do conferencista, durante todo o tempo da palestra, pouco mais de uma hora (...)"74. Em 8 de abril a palestra foi no Teatro Municipal, que, “apesar de não se encher por completo a vasta plateia”, recebeu público muito interessado. Essa apresentação foi dividida em duas partes: o primeiro tema do dia foi "A Capela da Montanha - Algumas igrejas do Brasil e suas tradições”. O segundo foi estritamente musical. Houve apresentação do coral da Escola Normal, dirigido pelo maestro João Gomes Junior, que cantou temas populares e composições do próprio maestro e de Alberto Nepomuceno. O público reagiu com arrebatamento à fala e "prorrompeu, por diversas vezes, em entusiásticos aplausos"75. Já em 1919 foi encenada postumamente no mesmo Teatro Municipal sua obra $O$ contratador de diamantes. Com bastante impacto e repercussão na imprensa desde antes da estreia, a peça de "atmosfera brasileira (...), exclusivamente brasileira", ambientada no período colonial, contava histórias da época dos bandeirantes e da mineração. Sua grandiosidade musical era revelada pelas duas orquestras: uma no fosso, regida por Francisco Braga - também responsável pela trilha -, e a outra dirigida no palco por Francisco Mignone, toda ela devidamente caracterizada ${ }^{76}$.

Acontece que o quadro paulistano era muito mais complexo nesta conjuntura nacional-regionalista, já que profundamente embaralhado

73 O Estado de S. Paulo, seção "Artes e artistas", 31 jan. 1915.

74. Idem. 5 e 6 fev. 1915 .

75 Correio Paulistano, seção "Registro de Arte", 8 abr. 1915. José Ramos Tinhorão faz referência a essas conferências no Teatro Municipal, indicando apresentação de "loas de Natal e de Reis, Cateretê do norte e um lundu do sul", uma marujada e um Bumbameu-boi. Ver TINHORÃO, José Ramos. Pequena história da música popular. São Paulo: Círculo do Livro, 1974. p. 196.

76 SEVCENKO, Nicolau. op. cit. p. 240-41. 
pela presença dos imigrantes e suas culturas, modos de vida e inúmeros sotaques. É de se presumir que essas pronúncias e tipos estivessem presentes no "teatro de revista" já que ele sempre estava voltado às questões e eventos do dia a dia. E os textos e falas das "conferências" de Cornélio Pires e da obra macarrônica de Juó Bananére refletiam muito bem essas misturas, assim como as trajetórias de músicos populares, como Roque Ricciardi (Paraguassú), Américo Jacomino (Canhoto), Anibal José Sardinha (Garoto), Raul Torres, entre tantos outros. É também de se supor a presença desses tipos estrangeiros no teatro musicado, sobretudo porque eles aparecem com tudo na década de 1930 na cultura radiofônica paulistana ${ }^{77}$, revelando um rico caldo cultural existente na cidade havia anos. Mas essa é uma questão que ainda exige investigação detalhada para tirá-la do silêncio.

Mesmo hesitando entre a "frivolidade" original e a "autenticidade" nacional ${ }^{78}$ em construção, a crítica tratou então de cobrar originalidade brasileira nos conteúdos musicais e de defender o teatro "sério" " "nacional", em oposição aos gêneros "ligeiros". Ela esperava da partitura e do libreto de caráter "regionalista" algo coerente com a temática "nacional", opondo-se mais uma vez a certa prática desenfreada da "colcha de retalhos". A crítica não costumava isentar-se de comentários negativos quando isso não ocorria. No julgamento da burleta Nhá moça, musicada pelo maestro Chagas Júnior, apresentada no teatro Boa Vista pela Companhia Arruda em 1919, isto ficou bem evidente: "a música da peça, sendo em parte um arranjo de operetas viennenses, está deslocada em uma peça regional". $\mathrm{O}$ que se destacava positivamente na parte musical eram somente " 4 ou 5 números espontâneos", porque relacionados à "espontaneidade popular" e que tipificavam o povo paulista ${ }^{79}$.

A partir deste momento, nas burletas e revistas de costumes paulistas o conceito de "típico" deveria obrigatoriamente aparecer na forma de números "bem brasileiros". No universo musical, isso significava um mundo sonoro composto de canções, duetos, desafios, cateretês, congadas, reisados e assim por diante. É justamente isso que o colunista de $O$ Estado destacava ao avaliar a burleta composta por João Felizardo e

\footnotetext{
SALIBA, Elias T. op. cit.; e MORAES, José Geraldo Vinci de. op. cit., 2000.

8 SALIBA, Elias T. op. cit.

79 O Estado de S. Paulo, seção "Palcos e Circos", 4 jan. 1919. Grifo nosso. A peça foi muito elogiada pelos "typos puramenta nacionaes, nos modos e na linguagem (...). Entre elles destaca-se o caipira Nho Juca, em que o característico da linguagem dos nossos roceiros não desfallece um momento sequer". Até porque o responsável pela Burleta, que era adaptação de uma peça argentina, era Abreu Dantas, pseudônimo "que esconde um nosso colega da imprensa".
} 
musicada por Modesto Tavares de Lima, cujo título já é bem representativo: Nossa terra e nossa gente: "A música é muito inspirada e tem números de uma delicadeza impressionante. É possível que a julguem monótona pela igualdade de seu motivo. É, entretanto, bem brasileira, muito nossa, e que por isso mesmo agrada a nossa gente (...)" ${ }^{\prime 0}$. E segue nesse mesmo tom ao avaliar a Flor do sertão, de Arlindo Leal, com música de Sotero de Souza, encenada pela Companhia Arruda em 1919:

(...) possue linda coletanea de musicas regionaes, da qual se destacam alguns números excellentes (...) o pequeno tango "Tristezas do caboclo", de Marcelo Tupinambá, o melhor número da peça, cantado por Antonio Dias; "Ierêrê", cantado por Edu Carvalho, e "Chora violinha, chora", por Antonio Dias, ambos do maestro Modesto de Lima (...). ${ }^{81}$

Agindo assim no cotidiano cultural da cidade, a imprensa e a crítica paulistana gradativamente alcançaram grande importância. Por meio de suas colunas tratavam de estabelecer hierarquias e critérios, distinguindo espetáculos, direcionando modelos para os compositores e formando o gosto do público. O jornal O Estado de S. Paulo, por exemplo, noticiava as informações e críticas sobre teatro musicado na coluna "Palcos e Circos", enquanto "Artes e Artistas" era dedicada aos eventos ligados à música erudita e certo conceito de "bom gosto" e "música séria", com notícias sobre maestros, intérpretes e instrumentistas brasileiros. Operava-se, assim, uma distinção entre a verdadeira "arte" e o entretenimento que, voltado exclusivamente à diversão, poderia resvalar no mau gosto para atrair a parcela mais humilde do público, o chamado "galinheiro".

Acontece que esse papel central ostentado pela imprensa não passou despercebido dos revistógrafos, uma vez que sua principal fonte de inspiração era justamente os acontecimentos do dia a dia da metrópole. Na revista Só pra falar, escrita pelo carioca radicado em São Paulo, Cardoso de Menezes, encenada em 1914, a imprensa tornou-se um dos personagens principais da peça, com direito a número musical próprio. No espetáculo há referência explícita à conhecida revista paulistana de variedades A Cigarra, que esporadicamente editava coluna de crítica do teatro musicado e algumas vezes inclusive apresentava excertos de partituras. Claro que, neste caso específico em que ela apareceu como

80 O Estado de S. Paulo, seção "Palcos e Circos", 2 jul. 1919. (Grifo nosso.)

81 O Estado de S. Paulo, seção "Palcos e Circos", 25 jan. 1919. (Grifo nosso.) 
personagem, $o$ fato foi destacado, apresentando a letra integral da canção em que o periódico é citado, acompanhada do trecho em pentagrama:

$\begin{array}{ll}\text { Eis-me, aqui estou } & \text { Eu provo arte } \\ \text { Bella e catita } & \text { Honras mereço } \\ \text { Sempre Art Nouveau } & \text { Vivo cantando } \\ \text { Sempre bonita! } & \text { Linda canção } \\ \text { Sou, com franqueza } & \text { E vou passando } \\ & \\ \text { Uma tetéa... } & \text { Mesmo um vidão } \\ \text { Sou a princeza } & \text { Sendo a Cigarra, no entanto, } \\ \text { Da Paulicéa } & \text { Mal o povo, enfim, me viu... } \\ \text { Por toda a parte } & \text { Imitou logo o meu canto: } \\ \text { Onde appareço } & \text { psiu! psiu! psiu! psiu! }\end{array}$

E o fragmento original da partitura reproduzido no periódico é o seguinte:
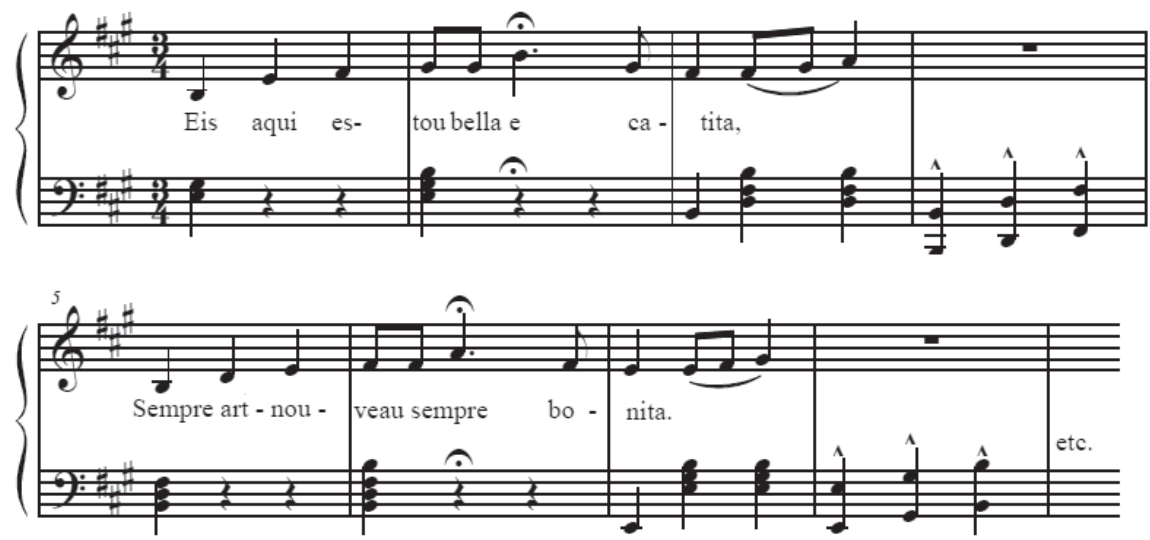

O manuscrito fornece algumas informações interessantes. É possível perceber, por exemplo, como a prática cancionista no teatro musicado ainda estava marcada pela performance oitocentista. As sequências de segundo e terceiro compassos revelam essa situação. As semínimas pontuadas (Si na primeira linha e Lá na segunda da clave de Sol) marcadas pela fermata pretendem evidentemente sustentar as notas e sílabas "indefinidamente", expondo a expansão e controle da respiração. Já nos terceiros compassos o legato ascendente indica que as notas (de Fá a Lá e de Mi a Sol, respectivamente) devem ser cantadas sem interrupção como se fosse uma só, circunstância em que o cantor mostra sua técnica e extensão de voz (embora o intervalo neste caso 
seja pequeno). Essas duas pequenas passagens revelam como a estética e a técnica do bel-canto ainda estavam presentes entre os cantores da cena musical. A crítica e o gosto do público costumavam valorizar essa "perfeição" no canto e as qualidades das vozes de cada ator ou atriz. Eram avaliados o timbre, a altura, a intensidade e extensão da voz, bem como sua adequabilidade ao papel representado. No entanto, o manuscrito aponta também para algumas dúvidas evidentes. A separação silábica exposta no pentagrama não corresponde à prosódia da letra publicada na revista, e a harmonia está confusa, já que não obedece à armadura da clave. As motivações para esses problemas podem ter sido geradas talvez pela má compreensão da música, pela costumeira dificuldade do músico popular com a notação, por dificuldades na edição da revista ou por todos esses motivos ao mesmo tempo.

\section{Último ato}

No último ato, talvez seja interessante sublinhar alguns aspectos presentes na cena musical paulistana na passagem dos séculos XIX-XX. Em primeiro lugar, destacar que a cidade de São Paulo, mesmo desempenhando papel secundário no circuito musical do país - sobretudo se comparada às cidades de crescimento urbano e de atividades culturais mais estáveis, como o Rio de Janeiro e Salvador -, construiu e manteve certa rede musical bastante ativa na época. Nela o teatro musicado desempenhou função importante para as novas experiências culturais urbanas e a difusão de todo tipo de música popular em construção.

Contudo, essas contribuições precisam ainda ser melhor compreendidas e matizadas, uma vez que foram realizadas em meio à imprecisa e complexa "misturada de gêneros", cuja "colcha de retalhos" teve que obrigatoriamente incluir outras tradições culturais como as dos caipiras e imigrantes. Mas é possível indicar desde já que esses espetáculos da cena musical criaram, ainda que de maneira precária, as primeiras possibilidades reais de profissionalização do músico e de artistas, recebendo e ao mesmo tempo preparando instrumentistas para outros ambientes musicais (nos cinemas, cafés, orquestras, bandas, etc.). E que, mesmo num quadro de instabilidade e confusão das formas teatrais, musicais e tradições culturais, o teatro musicado participou de maneira influente na formação de tipos, na construção do gosto e do público consumidor de música popular. Neste passo, tudo indica que a crítica também elaborou um discurso que contribuiu para a constituição e hierarquização do gosto, a promoção e consumo musical, participando 
da edificação dos múltiplos significados da música popular. Isso significa que a imprensa deixou de ser apenas divulgadora das informações musicais e dos espetáculos e assumiu papel protagonista no cenário da música popular na cidade.

Por fim, essa cena musical vinculada ao entretenimento seguiu aquela atraente dinâmica entre "o útil e o fútil". Realizando a intrigante e curiosa fusão "do sério consorciado com o frívolo" ${ }^{82}$, colaborando assim de modo ativo para construir e tipificar esse que seria um dos conflitos e traços culturais da moderna sociedade brasileira.

Compreender essa complexa dinâmica cultural em uma época de transição da cidade e de formação de uma dada cultura e música urbana não é empreitada simples. Mas metendo o nariz "onde ninguém mete (...) com a curiosidade estreita e aguda que descobre o encoberto" ${ }^{\prime 3}$, talvez se consigam trilhar alguns caminhos e seja possível retirar o tema do anonimato em São Paulo e ao mesmo tempo sacudir a indiferença e a preguiça de certa historiografia da música.

82 ASSIS, Machado de. O folhetinista. op. cit. p. 40. 83 Idem. 